\title{
FERMENTATIVE BIOHYDROGEN PRODUCTION BY ANAEROBIC, THERMOPHILIC BACTERIUM Thermoanaerobacterium aciditolerans Trau DAt ISOALTED FROM VIETNAM
}

\author{
Nguyen Thi Yen ${ }^{1}$, Lai Thuy Hien ${ }^{1}$, Nguyen Thi Thu Huyen ${ }^{1,2 *}$ \\ ${ }^{1}$ Institute of Biotechnology, Vietnam Academy of Science and Technology \\ ${ }^{2}$ Nguyen Tat Thanh University, *huyen308@ gmail.com
}

\begin{abstract}
Thermoanaerobacterium aciditolerans bacterium Trau DAt isolated in Vietnam had the hydrogen production capability under the anaerobic condition at $55^{\circ} \mathrm{C}$. Using glucose, the dark fermentation of strain Trau DAt for hydrogen production was performed in three different scales: the flask scales under the suitable (1) and optimal (2) conditions, and the automatic fermentor system Bio-Flo 110 (3). Under the suitable condition, the strain Trau DAt produced $330 \mathrm{ml}$ volume total gas (L-1) and hydrogen occupied $42.95 \%$ of gas total. Under the optimal condition, the maximum volume total gas of $701 \mathrm{ml}$ (L-1) was obtained and hydrogen occupied of $77.2 \%$ total volume gas. Based on results of RSM analysis and $\mathrm{pH}$ controlled examination, the dark fermentation of strain Trau DAt was performed under automatic fermentor system scale (Bio-Flo 110). 2.64 L total gas (L-1) was obtained by consuming $92.58 \%$ glucose and hydrogen volume occupied $94.85 \%$ of gas total. The maximum hydrogen yield of strain Trau DAt was $1.63 \mathrm{~mol} \mathrm{H} 2$ (mol glucose)-1. Obtained results showed the remarkable potentiality of Trau DAt strain in application to the larger fermentation scale for biohydrogen production in Vietnam.
\end{abstract}

Keywords: Thermoanaerobacterium aciditolerans, anaerobic, biohydrogen, dark fermentation, thermophilic bacteria, Vietnam.

\section{INTRODUCTION}

Hydrogen is widely recognized as a clean and efficient energy resource for future. It is the only common fuel that is not chemically bound to carbon. When hydrogen burns in air, it gives off nothing worse than water vapor and heat energy. Therefore, burning hydrogen does not contribute to greenhouse effect, ozone depleting and acid rain. The capability for $\mathrm{H}_{2}$ formation is widespread among microorganisms, but only a few of them have been investigated with a focus on biohydrogen production.

Both photosynthetic microorganism and fermentative bacteria can produce hydrogen. However, photobiological hydrogen production including photoautotropic and photoheterotrophic microorganism (purple-nonsurfur-PNS) requires wide land to set up, need light along metabolism, and PNS lack the capacity for the efficient conversion of sugar to hydrogen [9]. On the other hand, fermentative bacteria represent a promising means not only to reclaim energy from wastes in the form of hydrogen but also to utilize the wastes as sources. In addition, the dark fermentation using fermentative bacteria has many advantages: (1) It can produce $\mathrm{H}_{2}$ all day long without light; (2) A variety of carbon sources can be used as substrates even biomass; (3) It produces valuable metabolites such as butyric, lactic and acetic acids as by products; (4) It is anaerobic process, so there is no $\mathrm{O}_{2}$. Thus, the dark fermentation for hydrogen production is the best choice for commercial biohydrogen production $[1,4,5,9,12,14,20,23]$.

Production of biohydrogen through microbial fermentation is well known processes in which thermophiles have many advantages compared to mesophilic microorganisms concerning fast growth rates and their ability to degrade a broad variety of substrates. Furthermore, many thermophiles produce fewer types of undesired end products compared to mesophiles $[18,20]$. These advantages make the application of thermophiles for $\mathrm{H} 2$ production economical and technical feasible. By some above properties, hydrogen production of fermentative thermophilic bacteria has received 
Nguyen Thi Yen et al.

more and more attention $[2,8,15,16,17,19$, 24].

Although a limited number of thermophilic bacteria can convert carbohydrate into $\mathrm{H}_{2}$ with a satisfactory yield and productivity, an anaerobic fermentative hydrogen production process can be conducted by either pure cultures or mixed cultures. However, there are only few studies have been done by pure cultures of anaerobic, thermophilic bacteria to indicate the conversion of carbohydrates to hydrogen gas. High values of hydrogen produced per mol of utilized glucose have been reported by the hyperthermophiles Caldicellulosiruptor saccharolyticus and Thermotoga elfii [5, 20]. The hydrogen yields by thermophilic, anaerobic bacterium Thermoanaerobacterrium aciditolerans AK17 were up to $1.1 \mathrm{~mol} \mathrm{H}_{2}$ (mol glucose)- 1 and $1.0 \mathrm{~mol} \mathrm{H}_{2}$ (mol xylose)-1. The maximum $\mathrm{H}_{2}$ production yield was $2.53 \mathrm{~mol} \mathrm{H}_{2}$ (mol hexose)-1 by Thermonanaerobacterium thermosaccharolyticum PSU-2 [9, 12]. Results of earlier studies showed that anaerobic, thermophilic bacteria had a great potential to produce hydrogen in pure cultures. In this research, the hydrogen production capability of anaerobic, thermophilic bacterium Thermoanaerobacterium aciditolerans Trau DAt isolated in Vietnam was reported.

\section{MATERIAL AND METHODS}

\section{Strain and Medium}

The bacterium Thermoanaerobacterium aciditolerans Trau DAt belonging to culture collection of IBT (Institute of Biotechnology), VAST (Vietnam Academy of Science and Technology) was used in this study.

The basic medium used for enrichment and cultivation of $\mathrm{H}_{2}$ producing bacterium Thermoanaerobacterium aciditolerans Trau DAt was NMV medium [7].

\section{Cultivation and Analyses}

Fermentation under the suitable condition: Experiments were performed in $600 \mathrm{ml}$ serum bottles that contained $600 \mathrm{ml}$ of suitable medium based on our previous result [22].
Fermentation under the optimal condition: Experiments were performed in $600 \mathrm{ml}$ serum bottles that contained $600 \mathrm{ml}$ of suitable medium based on our previous report [21].

Controlled $\mathrm{pH}$ experiments: T. aciditolerans Trau DAt was cultured in two $150 \mathrm{ml}$ serum bottles which contained $150 \mathrm{ml}$ medium under optimal condition with initial $\mathrm{pH}$ 6.5. $\mathrm{pH}$ media of fermentative processes were estimated $4 \mathrm{~h}$ per time. When the strain grew, $\mathrm{pH}$ would be decreased. When $\mathrm{pH}$ reduced at $\mathrm{pH}$ 6.0, one bottle was keeping at constant value $\mathrm{pH}$ 6.0, the other was not controlled $\mathrm{pH}$ during fermentative process.

Fermentation under the 7 L automatic fermentor system scale (Bio-Flo 110): Experiments for hydrogen fermentation was performed in automatic fermentor system with 7 $\mathrm{L}$ fermentation solution under optimal condition. $\mathrm{pH}$ was controlled during fermentative process (initial $\mathrm{pH}$ at 6.5 and then, controlled $\mathrm{pH}$ at 6.0 ) by using $\mathrm{NaOH} 3 \mathrm{M}$.

For three above fermentative processes, $10 \%$ inoculums (v/v) that harvested after $16 \mathrm{~h}$ of pre-cultivation were added as inoculums. Fermentative processes were performed at $55^{\circ} \mathrm{C}$ in anaerobic condition. The evolved gas mixture was collected in gas collector at normal temperature and atmospheric pressure. Bacteria growth and glucose consumption, gas volume were estimated during fermentative processes by OD measurement, DNS assay [10] and water displacement method, respectively. The gas products were analyzed by gas chromatography GC-TCD (Thermo Trace GC-Thermo ElectroUSA) with a thermal conductivity detector. The batch experiments were continued until hydrogen production ceased.

\section{RESULTS AND DISCUSSION}

\section{Biohydrogen production by dark fermentation under suitable condition}

Based on results of suitable condition study [22], the dark fermentation by Thermoanaerobacterium aciditolerans Trau DAt was performed under the suitable condition at flask scale. Results showed that the strain Trau DAt entered stationary phase after $25 \mathrm{~h}$ 
cultivation and consumed about $7.3 \mathrm{~g}$ (L)-1 glucose (initial glucose concentration was $10 \mathrm{~g}$ (L)-1) (fig. 1). $330 \mathrm{ml}$ volume total gas obtained and hydrogen volume was $141.7 \mathrm{ml}$ (L)-1, occupying $42.95 \%$ total gas producer. Volume of $330 \mathrm{ml}$ total gas was stabled until ending $28 \mathrm{~h}$ fermentation (fig. 1). Hydrogen volume achievements in suitable condition were not as high as many earlier reports $[2,3,13,14,16]$.

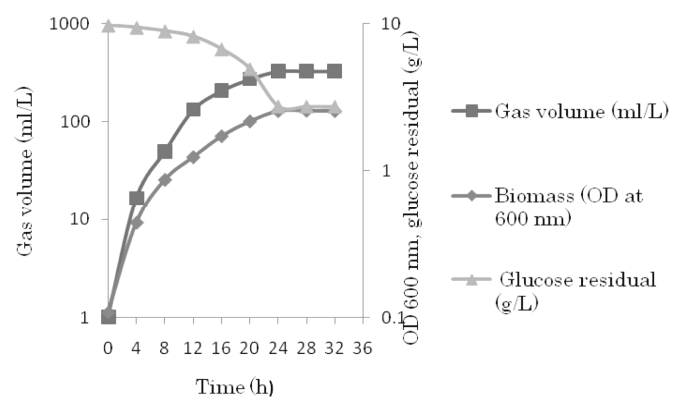

Figure 1. Capability of growth, hydrogen production, glucose degradation under suitable condition

\section{Biohydrogen production by dark fermentation under optimal condition}

Since the hydrogen yield of strain Trau DAt in suitable condition was not high in comparison to some other thermophilic strains, the response surface methodology (RSM) with central composite design was applied for three important factors including glucose, yeast extract, iron concentration to enhance hydrogen production yield. Experimental results showed that glucose, yeast extract and iron concentration all had significant influences and had a significant interactive effect on the hydrogen production potential. Based on RSM analysis, the optimal medium was NMV medium with optimal glucose, yeast extract, iron concentration [21]. Then, the dark fermentation was done in optimal condition based on the combination between the suitable condition and RSM results [21, 22]. Results in figure 2 showed that $\mathrm{H}_{2}$ production was accompanied with growth and glucose degradation. $\mathrm{H}_{2}$ production began when cell growth entered the early exponential phase $(4 \mathrm{~h})$ and rate of $\mathrm{H}_{2}$ production reached a maximum in the late exponential phase. The volume of produced $\mathrm{H}_{2}$ was high in the late exponential phase and early stationary phase. Strain Trau DAt consumed about $11 \mathrm{~g} \mathrm{(L)})^{-1}$ glucose (initial glucose concentration was $\left.12 \mathrm{~g}(\mathrm{~L})^{-1}\right)$ and produced $701 \mathrm{ml}$ volume total gas per volume of $1 \mathrm{~L}$ media, volume of $\mathrm{H}_{2}$ was $541 \mathrm{ml}$, occupying $77.2 \%$ total volume gas (fig 2). Hydrogen production of strain Trau DAt is still lower than the maximal hydrogen value of T. thermosaccharolyticum PSU-2, but higher than volume of $\mathrm{H}_{2}$ producing by Clostridium saccharoperbutylacetonicum ATCC at the same glucose concentration [6, 12]. Volume of $\mathrm{H}_{2}$ was produced under optimal condition was higher 3.8 fold than one was produced under suitable condition. This confirmed again that the capability of hydrogen production by Trau DAt highly depended on cultivation condition. It also indicated that RSM is a useful method to enhance the hydrogen production yield by bacterium T. aciditolerans Trau DAt. Furthermore, it was clear that the more improvable fermentative condition, the higher $\mathrm{H}_{2}$ yield of $T$. aciditolerans Trau DAt was obtained.

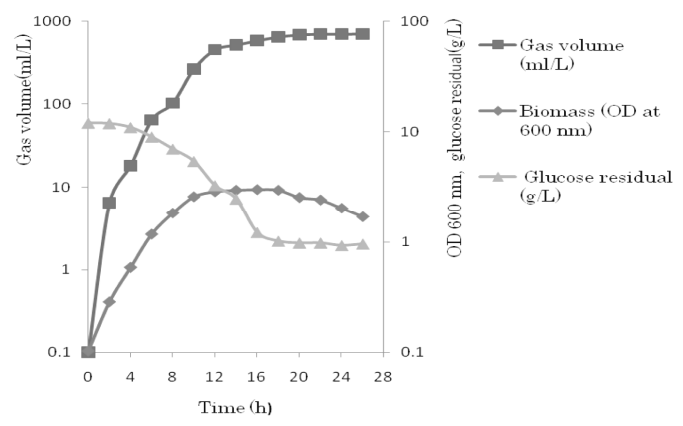

Figure 2. Capability of growth, hydrogen producer, glucose degradation under optimal condition at flask scale

\section{Hydrogen production under controlled $\mathrm{pH}$ condition}

Early research showed that capability of hydrogen producing bacteria depends on not only nutritional factors but also $\mathrm{pH}$. $\mathrm{pH}$ is one of the most important factors in hydrogen production due to its effects on $\mathrm{FeFe}$ hydrogenase activity, metabolic pathways, and 
Nguyen Thi Yen et al.

the duration of lag phase. Hydrogen fermentation processes produce by- product, which reduce $\mathrm{pH}$ of culture media [1, 7]. Khanal et al. (2004) reported that low $\mathrm{pH}$ values of 4.0-4.5 cause longer lag period. On other hand, high initial $\mathrm{pH}$ values such as 9.0 decrease lag time but have a lower yield of hydrogen production [7, 24].

Bacterium Trau DAt was cultured under optimal condition with maintainable $\mathrm{pH}$ and non-maintainable $\mathrm{pH}$ during fermentative processes. Results in figure 3 showed that $\mathrm{pH}$ of culture media started to reduce at $\mathrm{pH} 6.0$ after $12 \mathrm{~h}$. At this time, this train entered mid exponential phase, it also was time to produce $\mathrm{H}_{2}$. Therefore, maintainable $\mathrm{pH} \quad 6.0$ was performed in controlled $\mathrm{pH}$ case. In noncontrolled $\mathrm{pH}$ case, hydrogen fermentative process of $T$. aciditolerans Trau DAt was dropped when $\mathrm{pH}$ medium was reached to $\mathrm{pH}$ 4.0. In opposite case, $\mathrm{H}_{2}$ yield obtained higher. $700 \mathrm{ml}$ volume gas (L)-1 was produced in controlled $\mathrm{pH}$ case whereas $500 \mathrm{ml}$ volume gas (L)-1 was released in non-controlled $\mathrm{pH}$ case. It implied that hydrogen fermentation condition was favorably maintained by $\mathrm{pH}$ control in the cultures. Stable $\mathrm{pH} 6.0$ was optimal for T. aciditolerans Trau DAt to grow and produce $\mathrm{H}_{2}$. Alalayah et al (2009) also reported that the maximum rate of hydrogen production of Clostridium saccharoperbutylacotonicum N1-4 was measured at $\mathrm{pH} 6.0$ while the min rate of hydrogen production was recorded at $\mathrm{pH} 4.0$ [1].

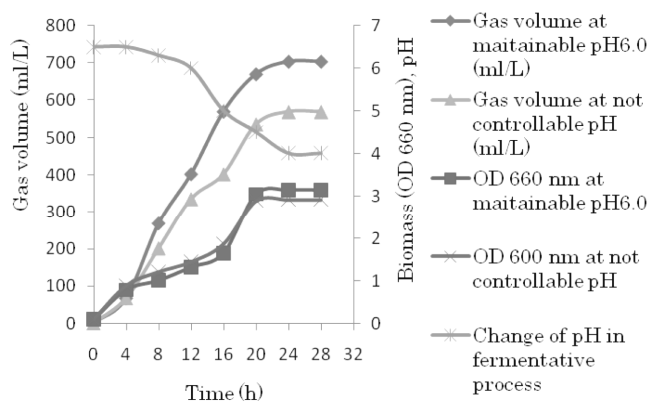

Figure 3. Capability of growth, hydrogen production with controlled $\mathrm{pH}$ and noncontrolled $\mathrm{pH}$ under optimal condition

\section{Dark fermentation for hydrogen production at fermentor scale}

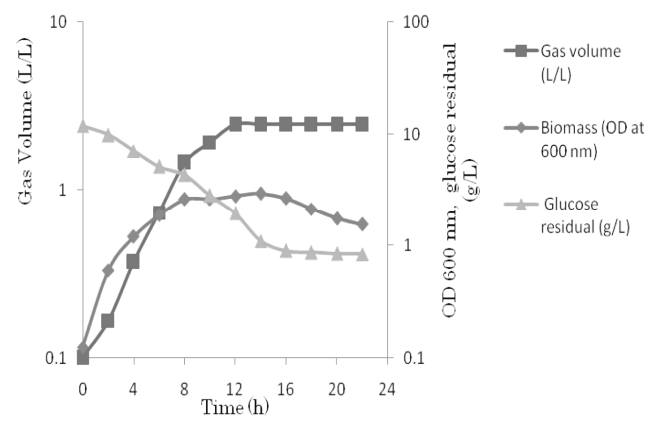

Figure 4. Capability of growth, hydrogen producer, glucose degradation under optimal condition in automatic fermentor system

Based on above result and our previous reports [21, 22], the dark fermentation of strain Trau DAt was carried out at automatic fermentor system scale (Bio-Flo 110) under condition: $12 \mathrm{~g}(\mathrm{~L})^{-1}$ glucose, $2.5 \mathrm{~g}(\mathrm{~L})^{-1}$ yeast extract, 400mg (L) ${ }^{-1} \mathrm{FeSO}_{4} .7 \mathrm{H}_{2} \mathrm{O}, \mathrm{NaCl} 0.5 \%$, meat extract $0 \mathrm{~g}(\mathrm{~L})^{-1}$, with $10 \%$ inoculums $(\mathrm{v} / \mathrm{v})$, initial $\mathrm{pH}$ at 6.5 and then $\mathrm{pH}$ was automatically controlled at 6.0 during fermentative process. Result showed that lag time lasted about 2 hours (fig. 4). It meant that initial $\mathrm{pH}$ at 6.5 was suitable for starting hydrogen fermentation. Exponential phase lasted about 12 hours, $\mathrm{H}_{2}$ was highly produced during this phase. This strain consumed $11.05 \mathrm{~g}$ $(\mathrm{L})^{-1}$ glucose $(92.58 \%)$ to produce $2.64 \mathrm{~L}$ total gas $(\mathrm{L})^{-1}$. The gas chromatography GC-TCD analysis showed that hydrogen volume was 2.50 $\mathrm{L}(\mathrm{L})^{-1}$, occupied $94.85 \%$ of gas total. It showed that $\mathrm{H}_{2}$ gas component obtained at automatic fermentor system was much higher than those at flask scale. It meant that the automatic controlled system was better than nonautomatic controlled one for hydrogen production of the strain Trau DAt. These results also indicated that the maximum hydrogen yield of strain Trau DAt was $1.63 \mathrm{~mol} \mathrm{H}_{2}$ (mol glucose $)^{-1}$. Maximum $\mathrm{H}_{2}$ production yield from different reported strains were compared with that of strain Trau DAt. Thermotoga elffi [5], Calidicellulosiruptor saccharolyticus [20], C. thermocellum [10], C. thermolacticum [3], 
Fermentative biohydrogen production by anaerobic

T. thermosaccharolyticum [12] and T. aciditolerans AK17 [8] were known of process $\mathrm{H}_{2}$ producing abilities under thermophilic and hyperthermophilic conditions corresponding to $2.7,3.3,1.95,1.5,2.53$ and $1.1 \mathrm{~mol}$ (hexose) $)^{-1}$, respectively. Strain Trau DAt had higher $\mathrm{H}_{2}$ yield than those of C. thermolacticum, T. aciditolerans AK17.

\section{CONCLUSION}

Obtained results of the present study showed that the hydrogen production capacity of Thermoanaerobacterium aciditolerans bacterium Trau DAt highly depended on fermentation condition. At flask scale, strain Trau DAt produced $330 \mathrm{ml}$ volume total gas, approximately $141.7 \mathrm{ml} \mathrm{H}_{2}(\mathrm{~L})^{-1}$ media and 701 $\mathrm{ml}$ volume total gas, in proportion $541 \mathrm{ml} \mathrm{\textrm {H } _ { 2 }}$ $(\mathrm{L})^{-1}$ media under suitable and optimal condition, respectively. Hydrogen fermentation condition was favorably maintained by controlled $\mathrm{pH}$ at $\mathrm{pH}$ 6.0. The maximum volume of total gas produced by the strain Trau DAt was $2.64 \mathrm{~L}$ corresponding to $2.50 \mathrm{~L} \mathrm{H}_{2}(\mathrm{~L})^{-1}$, equivalent to $1.63 \mathrm{~mol} \mathrm{H}_{2}$ (mol glucose) ${ }^{-1}$ under the optimal condition and maintainable $\mathrm{pH} 6.0$ in automatic fermentor system.

Acknowledgments: The authors gratefully acknowledge the financial support of Vietnam Academy of Science and Technology (Grant No. VAST 05.02/11-12). We also would like to express our thanks to Institute for Research and Development of natural products, Hanoi Technical University for their help in the gas analyses.

\section{REFERENCES}

1. Alalavah M. W., Kalil S. M., Kadhum H. A., Jahim M .J., Alauj M. N., 2009. Effect of Environmental Parameters on hydrogen Production using Clostridium saccharoperbutylacetonicum N1-4 (ATCC 13564). American J. Environ. Sci., 5 (1): 80-86.

2. Amorim C. L. E., Sader T. L., Silva, L. E., 2011. Effect of Substrate Concentration on Dark Fermentation Hydrogen Production Using an Anaerobic Fluidized Bed Reactor.
Appl. Biochem. Biotechnol DOI, 10.1007: 9511-9519.

3. Collet C., Adler N., Schwitzguebel J. P., Peringer P., 2004. Hydrogen production by Clostridium thermolacticum during continuous fermentation of lactose. Int. J. Hydrogen Energy, 29: 1479-1485.

4. Defeng X., Nanqi R., Manli G., Jianzheng L., Qiubo L., 2005. Monitoring of microbial community structure and succession in the biohydrogen production reactor by denaturing gradient gel electrophoresis (DGGE). Sci. China Ser. C. Life Sci., 48 (2): 155-162.

5. De Vrije T., de Haas G. G., Tan G. B., Keijsers E. R. P., 2002. Classen PAM. Pretreatment of Miscanthus for hydrogen production by Thermotoga elfii. Int. J. Hydrogen Energy, 27: 1381-1390.

6. Ferchichi M., Crabbe E., Hintz W., Gil G., Almadidy A., 2005. Influence of culture parameters on biological hydrogen production by Clostridium saccharoperbutylacetonicum ATCC 27021. World J. Microbiol. Biotechnol., 21: 855862.

7. Nguyen Thi Thu Huyen, Dang Thi Yen, Nguyen Thi Yen, Vuong Thi Nga, Lai Thuy Hien, 2012. Using of response surface methodology for optimization of biohydrogen production by Clostridium sp. $\operatorname{Tr} 2$ isolated in Vietnam. Tap chi Sinh hoc, 34(4): 497-484.

8. Khanal S. K., Chen W. H., Li L., Sung S., 2004. Biological hydrogen production: effects of $\mathrm{pH}$ and intermediate products. Int. J. Hydrogen Energy, 29: 1123-1131.

9. Koskinen P. E. P., Beck S. R., Orlygsson J., Puhakka J. A., 2008. Ethanol and hydrogen production by two thermophilic, ananerobic bacteria isolation from Icelandic geothermal areas. Biotechnol. Bioeng., 101: 679-690.

10. Levin D. B., Islam R., Cicek N., Sparling R., 2006. Hydrogen production by Clostridium thermocellum 27405 from cellulosic biomass substrates. Int. J. Hydrogen Energy, 31: 1496-1503. 
Nguyen Thi Yen et al.

11. Miller G. L., 1959. Use of dinitrosalicylic acid reagent for determination of reducing sugar. Anal. Chem, 31(3): 426-428.

12. O-Thong S., Prasertsan P., Karakasshev D., Angelidaki I., Thermophilic fermentative hydrogen production by newly isolated Thermonanaerobacterium thermosaccharolyticum PSU-2. Int. J. Hydrogen Energy, 33: 1204-1214.

13. Puhakka J. A., Karadag D., Nissila, E. M., 2012. Comparison of mesophilic and thermophilic anaerobic hydrogen production by hot spring enrichment culture. Int. J. Hydrogen Energy, 37(21): 16453-16459.

14. Ren Q. N., Wang Y. D., Yang P. C., Wang L., Li. F. Y., 2010. Selection and isolation of hydrogen-producing fermentative bacteria with high yield and rate and its bioaugmentation process. Int. J. Hydrogen Energy, 35(7): 2877-2882.

15. Romano I., Dipasquale L., Orlando P., Lama L., Ippolito G., Pascual J., Gambaccorta A., 2010. Thermoanaerobacterium thermostercus sp. nov., a new anaerobic thermophilic hydrogen-producing bacterium from buffalo-dung. Extremophiles 14(2): 233240.

16. Saratale D. G., Chen D. S., Lo C. Y., Saratale G. R., Chang S. J., 2008. Outlook of biohydrogen production from lignocellulosic feedstock using dark fermentation-a review. J. Sci. Indust. Res., 67: 962-979.

17. Sigurbjornsdottir A. M., Orlygsson J., 2012. Combined hydrogen and ethanol production from sugars and lignocellulosic biomass by Thermoanaerobacterium AK54, isolated from hot spring, Appl. Energy, 97: 785-791.

18. Jame R., Vilimova V., Lakatos B., Verecka L., 2011. The hydrogen production by anaerobic bacteria grown on glucose and glycerol. Acta. Chimica. Slovaca, 4(2): 145157.

19. Ueno Y., Sasaki D., Fukui H., Haruta S., Ishii M., Igarashi Y., 2006. Changes in bacterial community during fermentative hydrogen and acid production from organic waste by thermophilic anaerobic microflora. J. Appl. Microbio., 101(2): 331-343.

20. van Niel E. W., Budde M. A., de Haas G. G., van der Wal F. J., Claassen P. A., Stams A. J., 2002. Distinctive properties of high hydrogen producing extreme thermophiles, Caldicellulosiruptor saccharolyticus and Thermotoga elfii. Int. J. Hydrogen Energy, 27: 1391-1398.

21. Nguyen Thi Yen, Lai Thuy Hien, Nguyen Thi Thu Huyen, 2013. Optimization of medium components for hyrogen production of anaerobic bacterial strain Thermoanaerobacterium aciditolerans Trau DAT isolated from Vietnam by using response surface methodology. Tap chi Sinh hoc, 35(4): 469-476.

22. Nguyễn Thị Yên, Lại Thúy Hiền, Nguyễn Thị Thu Huyền, 2014. Nghiên cứu khả năng tạo khí hydro sinh học trong điều kiện kị khí của vi khuẩn ư nhiệt Thermoanaerobacterium aciditolerans Trau DAt phân lập ở Việt Nam. Tạp chí Khoa học và Công nghệ, 52(1): 73-82.

23. Yokoyama H., Moriya N., Ohmori H., Waki M., Ogino A., Tanaka Y., 2007. Community analysis of hydrogen-producing extreme thermophilic anaerobic microflora enriched from cow manure with five substrates. Appl. Microbiol. Biotechnol., 77: 213-222.

24. Zhang T., Liu H., Fang H. H. P., 2013. Biohydrogen production from starch in wastewater under thermophilic condition. J. Environ. Manage., 69:149-156. 


\title{
QUÁ TRÌNH LÊN MEN SINH HYDRO SINH HỌC CỦA VI KHUẨN LÊN MEN KỴ KHÍ, UAA NHIỆT Thermoanaerobacterium aciditolerans Trau DAt, PHÂN LẬP TẠI VIẸT NAM
}

\author{
Nguyễn Thị Yên ${ }^{1}$, Lại Thuý Hiền ${ }^{1}$, Nguyễn Thị Thu Huyền ${ }^{1,2}$ \\ ${ }^{1}$ Viện Công nghệ sinh học, Viện Hàn lâm KH \& CN Việt Nam \\ ${ }^{2}$ Trường Đại học Nguyễn Tất Thành, thành phố Hồ Chí Minh
}

\section{TÓM TẮT}

Vi khuẩn, Thermoanaerobacterium aciditolerans Trau DAt, phân lập tại Việt Nam có khả năng sinh hydro trong điều kiện kỵ khí ở $55^{\circ} \mathrm{C}$. Trong nghiên cứu này, quá trình lên men tối sinh hydro của chủng Trau DAt lên men tối sinh hydro được thực hiện ở ba cấp độ khác nhau: (1) lên men bình thí nghiệm trong điều kiện phù hợp, (2) trong điệu kiện tối ưu và (3) lên men trong thiết bị lên men tự động Bio-Flo $110(5 \mathrm{~L})$. Trong điều kiện phù hợp, chủng Trau DAt tạo được $330 \mathrm{ml}\left(\mathrm{L}^{-1}\right)$ khí và khí hydro chiếm 42,95\% tổng lượng

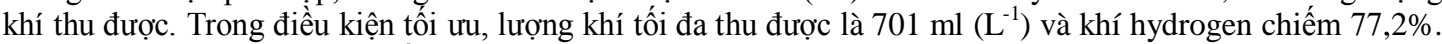
Sau cùng, quá trình lên men tối sinh hydro của chủng Trau DAt được thực hiện trong bình lên men tự động Bio-Flo $110(5 \mathrm{~L})$ trong điều kiện lên men tối ưu và $\mathrm{pH}$ được kiểm soát ở $\mathrm{pH}$ 6,0. Chủng Trau DAt đã tiêu thụ $92,58 \%$ lượng glucose ban đầu đẻ sản xuất $2,64 \mathrm{~L}\left(\mathrm{~L}^{-1}\right)$ khí và lượng khí hydrogen volume chiếm $94,85 \%$ tồng thể tích khí thu được. Sản lượng hydro cao nhất của chủng Trau DAt đạt 1,63 mol H2 (mol glucose)-1. Các kết quả thu được đã chỉ ra tiềm năng đáng kể của chủng Trau DAt trong việc ứng dụng để lên men sản xuất hydro sinh học ở qui mô lớn hơn tại Việt Nam.

Tù khóa: Thermoanaerobacterium aciditolerans, hydro sinh học, lên men tối, vi khuẩn kỵ khí, ưa nhiệt, Việt Nam.

Ngày nhận bài: 25-12-2013 